\title{
The planning and development of a district centre and the production of 'educated communities': the case of the Golden Grove development, South Australia
}

\author{
Caryl Bosman* \\ Griffith School of Environment, Griffith University, Gold Coast Campus, 4222, Queensland, Australia
}

\section{Introduction}

Over the centuries, many town planners have constructed relationships between the ideals of community and planning practices, with the intent of contriving particular social outcomes. This is perhaps nowhere more apparent than in the planning and development of contemporary master planned communities (MPC) (Bell, 2005; Dowling and McGuirk, 2007; Martin, 1996; Minnery and Bajracharya, 1999; Rosenblatt et al., 2009; Ryder 2003). Ted Rosenblatt et al. (2009, p. 132) state that the aim behind MPC is 'to provide friendly, safe and attractive living options on the suburban fringes of metropolitan centres for the relatively affluent and aspiring middle classes'. Partly to address this aim, MPC usually include a district centre comprising some or all of the following public and/or private services: retail, commercial, schools, recreational and cultural.

I analyse in this paper the planning, development and marketing of the Golden Grove Development - a MPC located on the fringes of metropolitan Adelaide in South Australia - district centre sites (schools, retail, recreational and cultural). The developers considered the district centre as the nucleus of the MPC. It was also the principal site through which ideals of the 'educated/good community' were to be produced, circulated and put into effect. Many of the rationales underpinning ideals of the 'educated/good community' are related, in some way, to established historical community-educational discourses. Much of this historical rhetoric links education to practices of everyday life; with the view to improving the wellbeing of individuals and therefore the well-being of the population and the economy. The developers of the Golden Grove site argued that the facilities included in the district centre would 'enhance the quality of life in the area' (South Australian Urban Land Trust \& Delfin Property Group, 1988, p. 2) and that 'the community at large must benefit from this richer breed of person' (South Australian Urban Land Trust \& Delfin Property Group, 1988, p. 8). The district centre was also considered by the developers as a site that would offer substantial economic returns through the implementation of prudent economic practices.

The Golden Grove Development emerged at a time (early 1980s) when neo-liberal rationales began to proliferate in Australia (Gleeson and Low, 2000). Proponents of the project considered ideals of community to be fundamental to the financial and social success of the new suburban development. This is evident in key Golden Grove planning, marketing, development, legislative and business texts, which point to the actual production of particular ideals of community. These texts stipulate the practices and techniques by which 'community' was to be achieved; practices and techniques that were significant in the Golden Grove Development being influential in the planning of other new residential developments across Australia (Boseman, 2007). In addition, the planning techniques and practices - and related ideals of community - that constituted the development were significant in it being awarded the 'Prix d'Excellence' and named 'The World's Best Address' by the International Real Estate Federation in 1998. In addition, in 2003, the Urban Development Institute of Australia named the development 'Australia's Best Development'.

The paper begins by describing the physical context for the Golden Grove Development. This is followed by locating the research in a theoretical context. A historical context of the relationships between planning, community and education practices is outlined to highlight the similarities and differences with the Golden Grove study. Following this, an account of the project planning legislation is provided. The links between government, education and community are then discussed in relation to the district centre sites. The remainder of the paper then focuses on these sites: the campus site and the public/ consumer precincts. An analysis of the rationales that drove the planning and development of the centre concludes the paper.

\footnotetext{
*Email: c.bosman@griffith.edu.au
} 


\section{Physical context}

The Golden Grove site is situated within the Tea Tree Gully Local government area, on the outskirts of metropolitan Adelaide, South Australia about $16 \mathrm{~km}$ north east of the CBD (Figure 1). The Golden Grove MPC covers a number of different suburban and postal code areas and it is because of this that I use the term 'the Golden Grove Development' when I refer to the MPC as a whole.

The topography of the MPC consists of rolling hills, a central plateau and deeply incised gullies. The development covers approximately 1230 hectares (Figure 2), 980 of which are allocated for building, 190 hectares for natural reserves and 60 hectares for green space (parks, playgrounds and ovals) (Golden Grove Community Planning Team, 1990). A hierarchy of roads within the development links into the wider road networks, allowing reasonably easy vehicle access to a regional shopping precinct and a hospital. Within the development there are 12 well established schools, both public and private, a Recreation and Arts Centre, an indoor heated pool, numerous netball and tennis courts, an all-weather hockey pitch, a ten pin bowling centre and a skate park. These amenities were planned to accommodate a residential population of approximately 30,000 people.

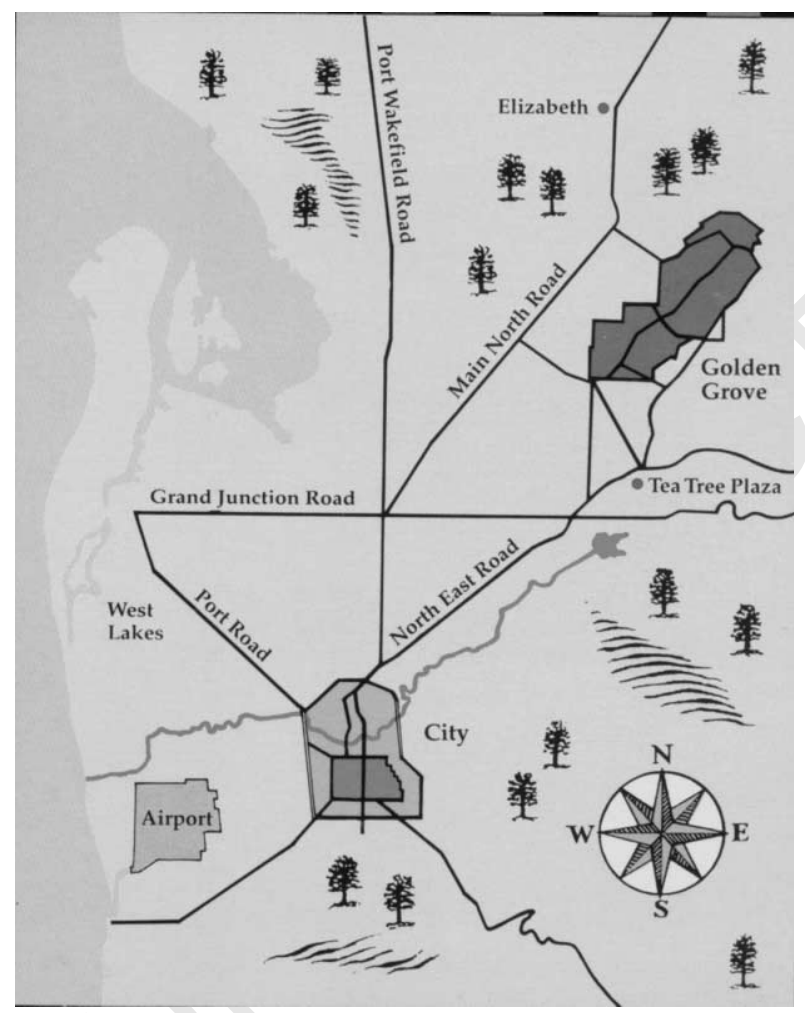

Figure 1. Golden Grove Development location map. Source: 'Everything you've ever wanted to know about Golden Grove'. Image courtesy of Delfin Lend Lease.

\section{Theoretical context}

\section{Community defined}

Ideals of community have been associated with the practice of planning for over a century and continue to play an important role into the 21 st century. Many planning discourses have promulgated ideals of community as being deterministically achievable, desirable, necessary, universal, good and 'truthful' (Hall, 1994; Hall and Porterfield, 2001; Haworth, 1976; Katz, 1994; Neal, 2003). From the 1990s, some individuals have re-questioned the meanings and formations of 'community', an indication that the word is, perhaps, problematic (Alperson, 2002; Freie, 1998; Frug, 1999; Gwyther, 2008; Young, 1990). Drawing on some of this planning for community literature, my research focuses on ideals of the 'educated/good community'; in particular, I draw upon those texts that informed the planning and development histories of the Golden Grove district centre. The developers of the Golden Grove Development, obligated by project specific planning legislation, planned, developed and marketed the district centre in accordance with the particular ideals of the 'educated community'. Based upon this supposition, I have adopted the phrase 'educated/good community' to emphasise particular relationships between ideals of community and pedagogics. Where possible, I refrain from using the word 'community' in relation to my own analysis and instead use the word 'collective', in order to avoid confusion between that which is being analysed and the analysis itself. In instances where I do use the word 'community' in relation to my own analysis I have identified this by using inverted commas and also to emphasise that the word is problematic.

\section{Theoretical framework}

In this paper, I analyse how particular Golden Grove Development ideals of the 'educated/good community' were produced in the district centre sites. That is, through specific planning techniques and practices which encompassed physical, social and pedagogical landscapes - the developers of the Golden Grove MPC endeavoured to build a suburban environment that produced and supported 'educated/good community' subjects, subjects who valued and engaged in specific educational, recreational and retail practices in accordance with particular, pre-determined codes of conduct. These codes of conduct were not instigated from positions of authority; rather, they were dependent upon the creation of environments that regulated conduct through practices of self-discipline and voluntary conformity. 


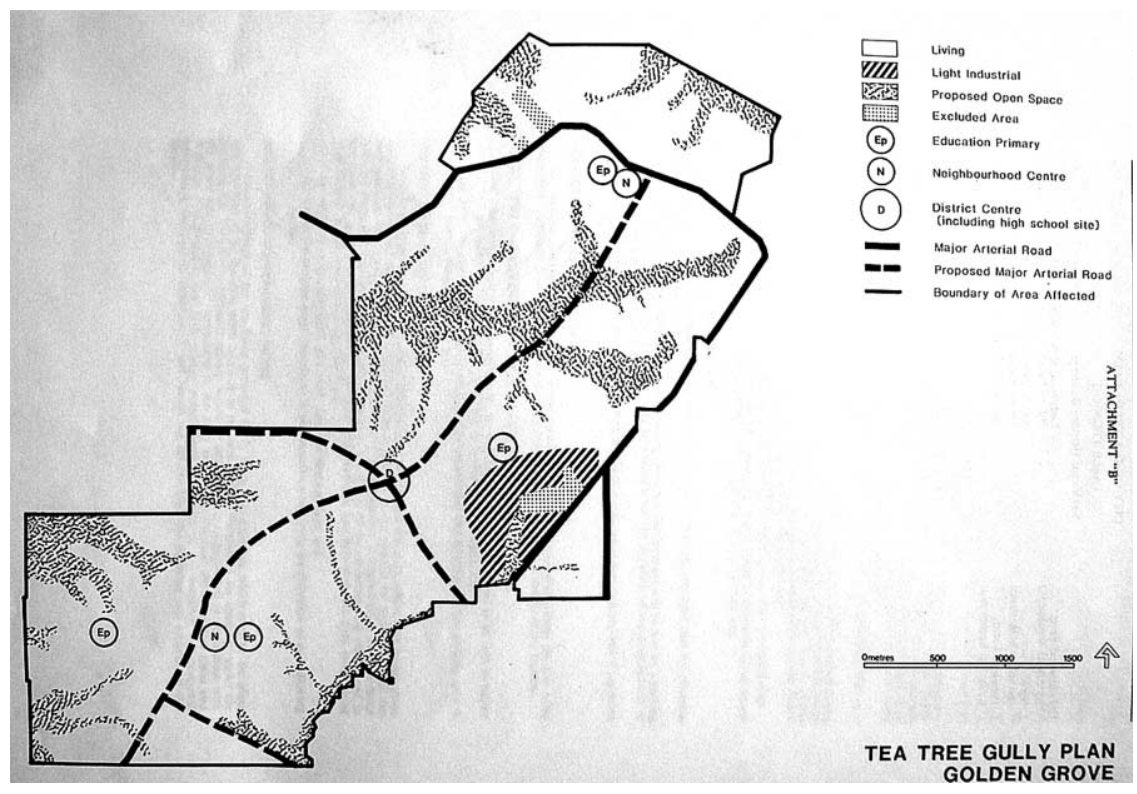

Figure 2. Golden Grove Development area plan included in the Golden Grove (Indenture Ratification) Act 1984. This plan is the foundation on which the planning and development of the MPC was based. Source, Golden Grove (Indenture Ratification) Act 1984.

The planning practices that informed the district centre compartmentalised and arranged educational, retail, commercial and recreational spaces to effect the economic and efficient sharing of resources and provision of services. It also ensured a hierarchy of rank or social spaces within each of the specified sites. The grouping of facilities would also regulate and save time for those who wished to participate in the available activities. A network of circulation routes aimed to link and separate activities, to effect the efficient movement/discipline of users. For example the location of school buildings, their relation to each other and the shopping precinct all suggest paths of travel and when, where and who may travel these paths.

Through the planning practices of zoning in particular, the conduct of individuals could potentially be economically and effectively governed. Margo Huxley (1994, p. 164) suggests that 'zoning reinforces existing exclusionary powers over space and creates new rationales for their exercise.' Particular activities, within the district centre, were/are allocated to specific sites: schools, recreation, shopping malls, fast food outlets, hardware and service stations are all zoned in accordance with their function and economic status. Shopping mall activities are located in the centre of the site as the prime consumer generators. The Home Hardware store (tucked behind a fast-food zone on the site periphery) was closed in 2009 and the building is currently occupied by a Cheap As Chips retail outlet. This retail outlet and the school and recreation activities are isolated from the shopping precinct by busy roads. Pockets of relative sameness are created both within the district centre site and within the various zones. This sameness often excludes other activities from taking place; for example the consumption of fast foods within the shopping mall or within the school grounds. In addition, the zoning of the district centre renders that which is not zoned for as invisible or non-existent, and therefore unproblematic. For example, the district centre did not allow for the provision of additional council services, in particular a library, workshop facilities and office accommodation, despite the fact that the site is substantial, underutilised and amenable to further development. A number of mixed use development proposals have been produced for the district centre site, however these developments have not materialised. The consequences of zoning, and therefore lack of diversity, are that most residents are required to find employment and work premises outside of the MPC.

The methods that underpin the analyses presented in this paper draw upon John Law and, in particular, his theories on allegory (Law, 2006, pp. 86-103). Law makes an argument for an assemblage of research methods as a legitimate approach to social science research. He includes allegory as a method in this assemblage. Allegory is that which is elusive or not explicated and is understood by a range of sociocultural, emotional and aesthetic conditions, among others. Law (2006, p. 88) explains that allegory as a 
method is the art of decoding meaning, reading between the literal lines to understand what is actually being depicted.'

In relation to this research, technologies of allegory involve reading the built landscape for what is not obvious. This paper then unfolds the possibilities of place and thus opens up opportunities to view/understand/practice planning differently. This approach is embedded in the knowledge that allegorically sourced and interpreted data are of equal value and importance to data that are descriptive and empirical. Indeed, Law (2006) argues that there is no such thing as a direct representation or description as all data are mediated by a host of complex and messy conditions. Description then is allegorical in that it takes the colour and flavour of the author's identity and situation at the time of scribing. As others have argued (Knudsen et al., 2008), there is no single 'truthful' reading of a landscape: we see it, read it, understand it, give meaning to it and experience it differently. My readings of the Golden Grove Development therefore say something about my intent in relating these interpretations; they also say something about who I am as a person. As I have already stated, the aim of this paper is to acknowledge and contest suburban government. It is not the intent of this paper to offer new and tangible suburban planning solutions. Instead, by focusing on the Golden Grove district centre discourses, this paper problematises planning techniques and practices that seek to produce 'community' as a tangible outcome.

\section{Planning: education: community historical context}

Many of the ideologies that underpin the planning practices employed in the development of the Golden Grove district centre can be traced back to much of the education-community rhetoric espoused by some social reformers of the late 18th and early 19th centuries. It is common for many planners and reform proponents to re-valorise and postulate ideals of community in times of technological, economic and environmental change. Ian Hunter (1994) suggests that educative systems emerged, at such times, to transform bounded residential collectives into resources (docile bodies) that would contribute to the well-being of the state in the face of perceived destructive forces.

The late 18th century British social reformer and town planner Robert Owen was one of the foremost advocates of education as a means to improve the wellbeing of individuals and collectives - and therefore the state. Owen's doctrine (Owen, 1969) was based on the power of reason; through the promotion of rational views, he believed, people would be persuaded of the 'truth' of the argument and conduct their lives in accordance with this 'truth'. Owen's villages of cooperation, or Owenite Communities, required subjects to conform to specified and specific codes of behaviour. It was through the practices of education, he argued, that subjects' everyday lives would be shaped and conditioned; children and adults would learn how to become happy, rational, employable subjects; that is, good, economic, social citizens. Owen's quest for the 'good community' required subjects to be disciplined, docile and obedient; factors that limited the appeal of his reform discourses and resulted in their relatively short-lived popularity.

At a micro scale, Owen sought to regulate the conduct of bounded residential collectives through the government of the individual. The principal means by which this aim was to be achieved was through the implementation of specific town planning practices. These planning practices revolved around residential allotment layout and house design, provision and location of schools and recreation spaces, and the provision for employment opportunities. Owen considered these practices to be unproblematic and unquestionably good in that they would result in rational, happy, healthy, self-regulating individuals and collectives. In effect, Owen aimed to optimise the capabilities and usefulness of the individual and thus the collective, in order that the collective might then govern the conduct of the individual. That is, the techniques of government employed to regulate the conduct of the individual would be reflected in the government of the collective.

Another influential educational reformer and 'community' promulgator was the American philosopher John Dewey (1859-1952). Dewey has been acknowledged as being 'the most influential thinker on education in the twentieth century' (Smith, 2001). Like Owen, Dewey's philosophy was based on pragmatism, interaction, 'community' and democracy. Dewey (1897) believed that education:

must begin with a psychological insight into the child's capacities, interests, and habits. It [the child] must be controlled at every point by reference to these same considerations. The powers, interests, and habits must be continually interpreted - we must know what they mean.

For Dewey, education was a social practice; a practice that reflected the child's life patterns in the home, neighbourhood or playground. Dewey (1897) saw the school as a 'form of community life'; an institution that fostered 'proper relations with others in a unity of work and thought.' Like Owen, Dewey advocated the belief that education was fundamental to social reform and the creation of the 'good community'. 
While Owen sought to establish the 'good community' largely through deterministic and autocratic value judgements, Dewey sought to create the same through an assemblage of 'scientific' knowledges.

Foucault (1991) argues that this shift in approach, from value judgment to scientific knowledge, was indicative of political and social changes of the time. By the late 19th century, most schools had become venues for gathering and recording knowledge about students. The personal characteristics of students were commonly assessed and evaluated, the ultimate aim overtly or covertly expressed - being to create obedient and useful subjects. Educational practices were, potentially, both economical and successful as they drew upon and reinforced the physical and psychological capabilities of the student. The role of education thus becomes ethical as it seeks to influence everyday life patterns; a premise that has persisted in the texts of most educational histories relating to residential collectives, including the histories of the Golden Grove district centre, as this study demonstrates.

\section{Golden Grove planning and legislation context}

In Australia in the 1970s and early 1980s, the promulgation of ideals of community was popular among many social policy professionals (planners, educationalists and politicians) (Everingham, 1995; Wild, 1981). It was within this context that the MPC - later to be named the Golden Grove Development was conceived. The planning techniques advocated in the initial planning documents for the Golden Grove site informed the legislation that formalised and formularised the planning techniques and practices that were carried out on the site. These techniques and practices affected both the physical landscapes and the production of ideals of community. It is not within the scope of this paper to discuss the details of the planning and legislative contexts for the Golden Grove Development (see Bosman, 2005, 2009), nonetheless it is important briefly to outline the key documents.

Development of the Golden Grove MPC was first proposed in the 1962 Metropolitan Development Plan (MDP) for the City of Adelaide. The MDP was the first attempt since the 1930s, in South Australia, to implement planning policies that were pro-active and visionary. As with other Australian metropolitan planning strategies of the time, the Adelaide plan was primarily concerned with development on the urban fringe and it zoned large tracts of rural land for future residential development. This land zoning included the site that was later to become the Golden Grove Development Area (see Murphy, 1993, for oral histories relating to the development area).
The initial planning of an MPC for the site began in the early 1970s and continued through to 1984 with the passing of the Golden Grove (Indenture Ratification) Act. Ideals of community remained paramount in the planning documents throughout this period. However, the meanings and values attributed to these ideals mutated from those associated with welfarist techniques of government to those aligned with neoliberalism. These mutations are evident in the many documents produced under (the auspices of) the different state Governments (both Labor and Liberal) in power during the gestation period (Northage \& Associates 1983; South Australian Land Commission, 1979; Tea Tree Gully (Golden Grove) Development Committee, 1980; Tract, 1976a, 1976b). This suggests that ideals of community are inherently unstable and are context reliant rather than being universally true.

The most important document that informed the planning and development of the Golden Grove site was the Golden Grove (Indenture Ratification) Act 1984. This Act included a number of documents that set out the political, financial and social conditions for the development of the MPC. The Act named the developers of the site as a joint venture partnership between a private developer - Delfin Limited, now Delfin Lend Lease - and the state government. The indenture documentation gave the joint venturers powers of planning and development approval, thus bypassing the existing statutory planning process. Significantly, the state government had ownership of the land that was to comprise the MPC, and the Indenture stipulated the arrangements for the private enterprise partner to purchase the land consecutively over a period of 20 years at a fixed price.

The indenture documentation also included ten Paramount Objectives, which were to govern the developers specifically in the building of a 'community'. In effect, the Golden Grove (Indenture Ratification) Act 1984 gave the developers the authority to interpret, design, plan, implement develop, market and sell an MPC in accordance with the Indenture and market processes. It is important to note that no monitoring, compliance or quality assurance processes were included in the documentation. The Act did, however, oblige the developers to adopt an 'ethical and commercial' manner in all their dealings. In this case, ethical practices of government are tied to market processes and ascribed a commercial value. This suggests that developers would only pursue those ethical practices that offered good economic returns. In many respects, perhaps not surprisingly, this proved to be the case (Bosman, 2005, 2007) and particularly so in the planning and development of the district centre sites. 
The idea of a suburban district centre can be traced back to the aforementioned 1962 Adelaide Metropolitan Development Plan. In the context of the MDP, the meaning of 'centre' was predominantly retail. In the early planning of the Golden Grove site it was extended to include 'retail, commercial, recreational, educational, social, and welfare facilities... grouped together to provide a focus for community activity and therefore an interforce [sic] between residents' (L.G. Curtis 1977, p. 6). The 1979 Development Area study (South Australian Land Commission, 1979, p. 13) suggested that the co-location and multi-use of facilities would 'give the community a real and maximum choice' and thus 'provide opportunities for more vital communities.'

The 1980 Development Scheme (Tea Tree Gully (Golden Grove) Development Committee) district centre proposal suggested that the provision and colocation of basic residential requirements would be economic in terms of dollars, time and space. This proposal also argued that residents would be afforded freedom of choice and that social equity would be established; in that all residents would, allegedly, have equal access to a range of facilities. The eventual location, planning and development of the Golden Grove district centre was determined partly in accordance with these early plans and partly to minimise risks and maximise spatial, temporal and financial efficiencies, as discussed later in the paper.

Prior to the passing of the Golden Grove (Indenture Ratification) Act 1984, Delfin had notionally located a district centre zone on a plateau situated approximately in the centre of the development area. The site was at the proposed junction of two major arterial roads running north-south and east-west across the development (see Figure 2). This concept included a district shopping precinct - the Golden Grove Village Shopping Centre, a regional multipurpose community facility - the Golden Grove Recreation and Arts Centre, a shared secondary schools campus; and a district sports facility (see Figure 3). The South Australian minister of education at the time of development, Mr Greg Crafter, described the complex as 'the most modern, innovative and exciting education and community complex being developed in Australia' (Smith, 1988).

\section{Government: education: community context}

During the early years of the Golden Grove Development's gestation period, the Australian Federal Labor, Whitlam, government's (1972-1975) community schools policies reflected many of the rationales underpinning Owen and Dewey's community-education discourses outlined earlier. According to David Pettit

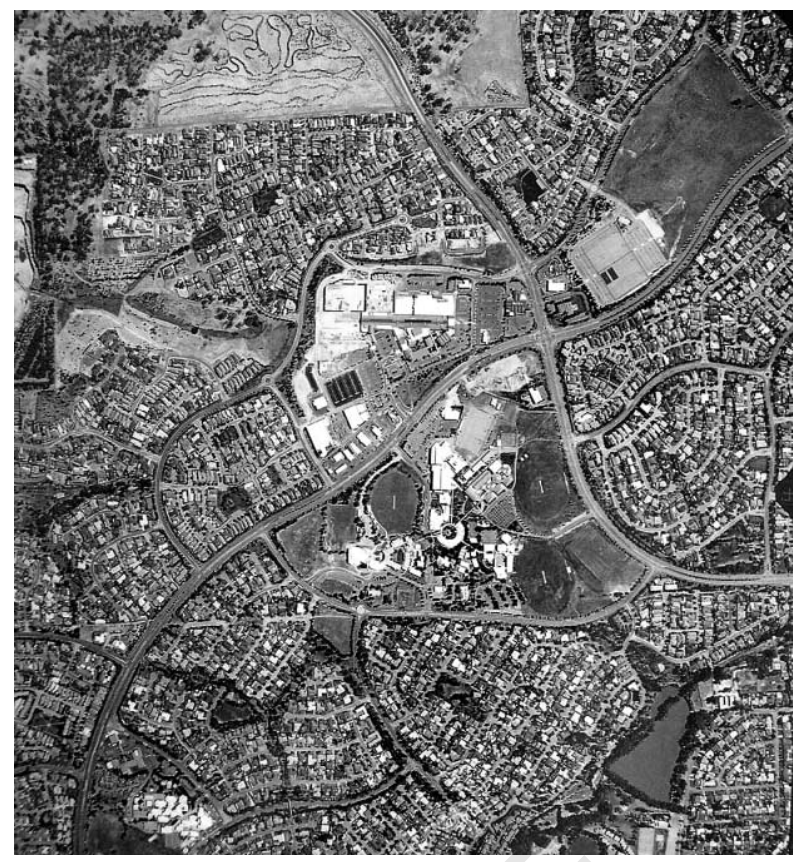

Figure 3. The district centre is centre comprises the shopping precinct; (left centre), the district sports field (top right) and the secondary schools campus and recreation centre (lower centre). Source, courtesy of, MAPLAND, Department for Environment and Heritage.

(1980, p. 12), the Whitlam government considered schools to be a 'community resource' and 'an integrating force in the life of the community'. Pettit (1980, p. 15) argues that 'Community involvement in educational programmes was seen as a way of lessening the school's isolation, extending its educational influence, reinforcing pupil motivation and increasing direct accountability to the community.' As such, local residential collectives are not considered independent from educational institutions, rather as extension of them. Welfarist techniques of government are frequently characterised by the direct involvement of the government (the institution) in the regulation of subjects' everyday conduct. In this instance, the Whitlam government sought to divest - and thus extend - its governance to local residents. This mode of government is, potentially, more efficient, effective and economical, in that, local residential subjects - in particular, parents - are assumed to be in a position to act swiftly and to the best advantage. For example parental supervision of homework potentially allows for the efficient and effective assessment of the student's academic progress. In addition, the governance of the student's moral behaviour and dress code, by both local residents and parents, renders the student an object under constant surveillance. Complying local residents and parents become adjunct teachers, or institutional agents, who take responsibility for and 
carry out the work of the government, within the micro spaces of the everyday.

The discourses of the district centre, produced primarily under the South Australian Bannon Labor government (1982-1992), largely reiterate the governmental approach that had been previously adopted by the federal Whitlam government with regards to the active involvement of local residents and parents within sites of education. There is, however, a fundamental difference between the Whitlam welfarist techniques of government and those produced by the discourses of the district centre. The subjects who were to be governed under the welfarist state are conceived, within the district centre discourses, as autonomous and free individuals who choose paths that will further their own interests. The relations between the educational agents and the student change from one of intervention - as in the welfarist state - to one of abstention. In the discourse of the district centre, the school authorities, parents and residents maintain disciplinary codes, while the student is positioned as being an autonomous and selfregulating subject. These students promote social well-being through self-disciplined responsibility and active enterprise (Keogh, 1996, p. 124).

The production of ideals of the 'educated/good community', as suggested by the district centre discourses, required both the active involvement of educational institutions, students, local residents and parents. Jayne Keogh (1996) suggests that official educational rhetoric often constructs the 'good parent' - and I would add, the 'good community' as being active in the space of the school. This engagement, she notes, is frequently viewed by the school as indicative of parental support and commitment 'to the school's moral order'. As outlined, both Owen and Dewy advocated a fusion between the school and local residents; where education was to emulate positive, moral, disciplined values and behaviours of the residential subject, which, in turn would reinforce the mores of the collective. The developers of the Golden Grove district centre stated that (South Australian Urban Land Trust \& Delfin Property Group, 1988, p. 8):

The most outstanding product of Golden Grove's composite nucleus [the district centre] ... will be the expanded education that young adults can obtain through integration with the community and exposure to a greater range of people experiences. Golden Grove's community/education complex [the district centre] responds in a positive way to young adults' expanding demands for certain rights and freedoms. In return, the community at large must benefit from this richer breed of person.
Through the co-location of specific facilities and the implementation of particular planning practices, secondary school students would, supposedly, benefit from an expanded education. This echoes the policies of the Whitlam government. In addition, secondary school students were positioned under continual surveillance, by virtue of their being 'exposed' to users of the consumer spaces of the district centre. Surveillance as a disciplinary technique is efficient, effective and economical. Students are required to be active in their own regulation and discipline at all times; never certain when, where, how - video camera, consumer or retailer gaze - or if at all, they are being watched and monitored.

\section{The campus site}

The 46 hectare, shared secondary schools campus was the key component of the district centre site and the first segment of the centre to be developed (April 1988). The rationales underpinning the planning and development of the secondary schools campus set the precedent for planning and development practices that comprise the district shopping precinct and the recreation and arts centre. Prior to the passing of the Golden Grove (Indenture Ratification) Act 1984, Delfin had solicited support for a shared secondary schools campus from the Catholic Education Authority and the state Education Department. An invitation to join the shared campus venture was later given to an Anglican and Uniting Church consortium, which was looking to establish a secondary school in the area. To coordinate and manage the provision of these and other proposed schools, the Golden Grove Education Services Planning Committee was established in May 1984.

By December 1986, a blueprint for the secondary schools campus was in place. This was given as the outcome of 'genuine consensus' (Mayfield and Trimper, 1989) between the state and local governments, school representatives, and the developers. The Golden Grove Development model included: three secondary schools - two private and one government; a shared use facility; and a horticultural training facility to be run by Bedford Industries. Bedford Industries is a commercial organisation which proposed linking into the wider campus as a site for biology and environmental sciences. The organisation's principal focus was to train intellectually and physically handicapped people and equip them for the general workplace. This component of the campus, however, never eventuated due to the uncertain economic climate of the late 1980s and early 1990s - an outcome that suggests that economic 
rationales were to be given preference in the bid to create ideals of the 'educated/good community'.

\section{Public/consumer district centre components}

The district sports field, regional multi-purpose community centre and district shopping precinct comprised the major public components of the district centre. These sites were considered by the developers as extensions of the secondary schools campus, both physically and pedagogically; intended to mould and regulate the conduct of both students and local residents in accordance with specific ideals of the 'educated/good community' as suggested later in this paper.

The location of the district sports field site was largely the outcome of strategic urban planning processes and marketing strategies carried out by the developers rather than in response to topographic suitability. Given the topography of the site - steep and undulating - the developers undertook to fund a degree of landfill in a bid to convince the local council to develop the site. The council had not been involved in the choice of site, the proposed function, or the earthworks that were carried out; earthworks that the council maintained were neither compatible nor suitable for a district sporting venue. As a result, the Tea Tree Gully Council decided to construct a district sports field elsewhere in the council area. By October 2009, the site allocated for the district sports field had been cleared but not yet developed.

The district shopping precinct and the regional multi-purpose community facility were not to suffer the fate of the district sports field. Both sites, chosen by the developers, were subject to a series of stringent planning and development controls, stipulated and implemented by the developers.

The first stage of the shopping precinct was not completed until seven years into the life of the Golden Grove Development. By 1992, the population of the new development had reached approximately 11,500 , a figure at which the developers considered a district shopping centre would be economically viable (Delfin Management Services, 1992). The centre was designed as a meeting place that depicted a "neighbourly Village style shopping experience [that would] become the focal point for community shopping and social activity' both locally and council wide (Village Shopping Centre publicity brochure c1992) (see Figure 4). The design of the 'Village' included an enclosed shopping mall and a 'village square'. Shop tenancies framing the village square were given over to a post office, financial institutions (all of which had closed down by 2002, with some reopening in

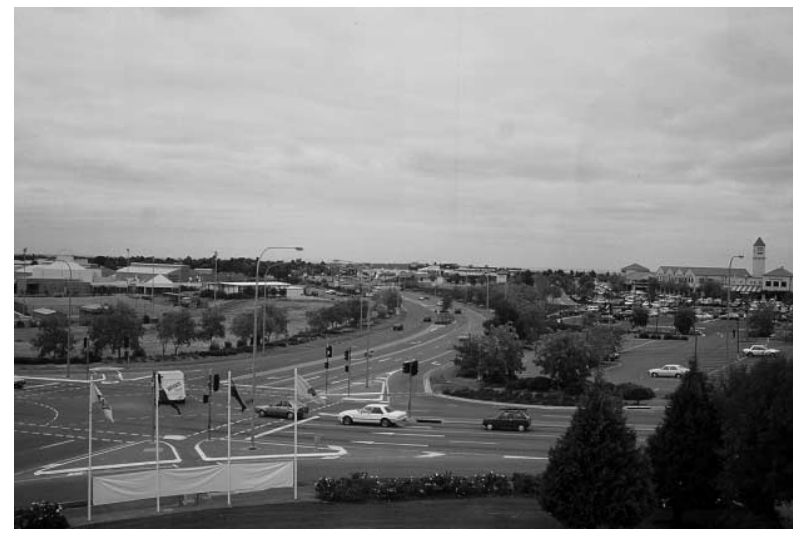

Figure 4. The multi-purpose community centre and secondary schools campus (left) are separated from district shopping precinct (right) by a major arterial road. This road runs the entire length of the development and does not allow easy nor safe pedestrian or cycle access to or between the district centre sites. Photo by the author 2004.

recent years), and associated human services (which never eventuated).

The remainder of this paper looks at the different rationales for the development of the Golden Grove district centre. As stated at the beginning of the paper, the purpose of these analyses is to illustrate how the Golden Grove district centre discourses worked or not to produce 'educated/good community' subjects.

\section{District centre rationales}

In keeping with the 1970s-early 1980s Golden Grove district centre planning proposals, the developers considered the site to be 'vital to the health of the whole project' (South Australian Urban Land Trust \& Delfin Property Group Limited, 1986, p. 10). The district centre was to present an image of a wellplanned and successful new residential development. Through a particular combination of facilities in a planned and ordered environment, the developers proposed providing a lifestyle that encompassed everything pertaining to the good life; economic viability, social interaction, recreation, education and retail opportunities all within easy access. Given the importance conferred on the district centre site, the developers sought direct control of planning, project management, marketing and development. The financial investments the developers made in the development of the district centre were substantial. They were both owners and developers of the district shopping precinct; the regional multi-purpose community facility was backed by funds provided by the developers; and the shared secondary schools campus was a Delfin initiative backed by joint venture funds. 
The developers were thus in a position to shape the urban environment in accordance with specific objectives, backed by project specific legislation, with the aim of producing particular ideals (explicit or otherwise) of the 'educated/good community'.

\section{Co-location rationales}

The developer's concept of the 'educated/good community', as a by-product of the co-location of pre-determined residential needs/requirements was primarily an economic practice: temporal and financial (infrastructure and consumer). The indenture legally bound the developers to adopt economic business practices that would offer maximum returns. The co-location of schools, shops, cultural and recreational facilities allowed for economic savings in relation to common trenching of services and the sharing of car-parking, school facilities and playing fields. In addition, savings could be had in terms of personal time, as multiple tasks - collecting children from school, shopping, socialising, recreating - could be undertaken within the one central location.

Partly to facilitate interaction between students and the shopping precinct users, initial planning proposals linked the shopping precinct and the secondary schools campus via an overpass. This link was promoted and supported by the local council in a bid to address concerns held by the council regarding students crossing the potentially dangerous roads (see Figure 5). The overpass was to be an artery that facilitated social interaction, education and ideals of the 'educated/good community'. This was a novel idea as most shopping centres have policies and procedures that actively discourage young adults from lingering or socialising on their premises unless they are engaging in legitimate consumer practices.

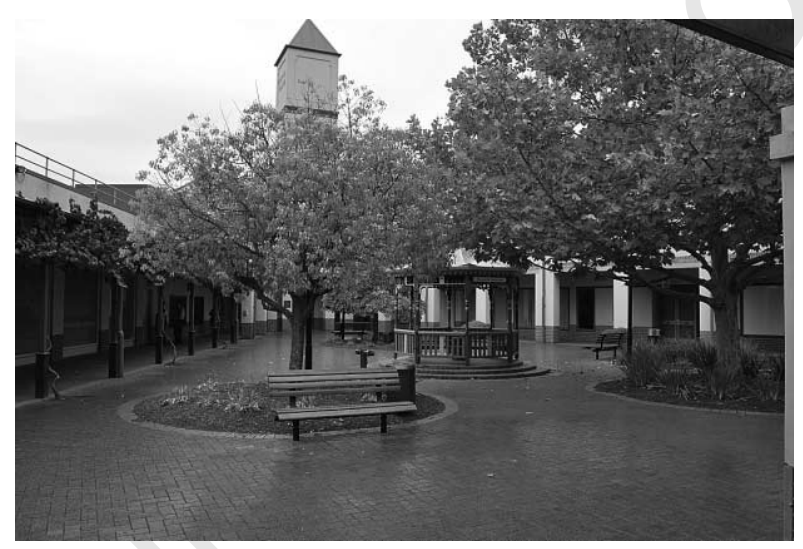

Figure 5. A 'community' 'focal point', the village rotunda in the village square; Golden Grove Village Shopping Centre. Photo by the author taken in 2003 on a Saturday morning.
The overpass was to be paid for by the developers as part of the district centre development. Although sketch designs for the link were commissioned, the overpass was never constructed. This was largely due to difficulties posed by the site and related structural issues, which proved to be financially unviable rather than physically impossible. As a consequence, most students negotiate a four lane major arterial road to catch their bus or partake of the commercial and retail services in the shopping precinct.

The assumption by the developers that the co-location of a range of specifically chosen facilities would result in positive and beneficial interaction ideals of community - between users is problematic. The distance between district centre facilities and the compartmentalisation of land uses does not allow for easy access between facilities other than by motor vehicle. In addition, many studies suggest such planning practices have little impact on the level or quality of user interaction (Holmes, 1995; Richards, 1991; Rosenblatt et al., 2009; Talen, 1999, 2000). Ideas of the 'educated/good community' are not reliant upon the physical arrangement of built forms, rather they are fluid and resist and co-opt the intent of planners and developers. In addition, the zoning of the district centre activities was put in place to limit the extent of user interaction, as outlined earlier. Debra Costley (2006, p. 157) however suggests that 'developers of MPCs have an opportunity to influence the development of successful communities' primarily through the planning and development of district centres.

\section{Social mix rationales}

The developers saw the shared secondary schools campus, in particular, as a site that would foster bonds of 'community' among people from different backgrounds. This was to be accomplished through the co-location of both private and government schools on one campus. This technique was not unique. In the early 1970s, the Whitlam government advocated social mix in schools as a means to reduce the effects of inequalities. Whitlam argued that social segregation in schools usually resulted in some students not having role models and leaders, which potentially perpetuated poverty and deviance. On the other hand, other students would not be privy to the predicaments of those different from themselves. This, Whitlam (1971, p. 710) argued would perpetuate attitudes of social polarisation. In the 1980s, Hugh Stretton (1989, p. 108) also argued for social mix in schools as a means to 'raise the infectious proportion of ambitious learners and stayers in the schools, increase the local resources and demands for 
school improvements, and improve the general standards of parental cooperation and vigilance.'

A critical assumption underpinning these social mix arguments is that students and parents from different socio-economic backgrounds would interact and that this interaction would educate the proletariat in accordance with middle-class hegemony; the 'educated/good community'. This strategy was particularly relevant as the north eastern suburbs, in which the Golden Grove Development is located, have a significant population of people from nonEnglish speaking backgrounds.

Some of the literature on the social benefits of propinquity and social mix however suggest this ideology is problematic (Gwyther, 2008; Talen, 2002). Gwyther (2008, p. 12) suggests that 'In the socially mixed neighbourhoods of the mobile society [such as the Golden Grove Development] disparate life-worlds seem unlikely to collide without internal effort or external force.' In the case of the Golden Grove secondary schools campus, one private school provider, in response to parental concerns, is known to have forbidden its students from mixing with students from the other schools during recess (personal communication, 2004). In addition, each school has its own grounds and, although the boundaries were not fenced in 2004, students were actively discouraged, at all times, from walking through or across the neighbouring school property.

\section{Concluding comments}

In this paper I have analysed the planning, development and marketing of the Golden Grove Development district centre sites. The developers considered the district centre to be the heart of the MPC. It was also the principal site through which ideals of the 'educated/good community' were to be produced, circulated and put into effect. The pre-occupation with the production of ideals of community was one that was legislated by indenture. It was also a theme that the developers harnessed and developed to market and sell the MPC. As this paper has demonstrated, many of the rationales underpinning ideals of the 'educated/good community' were related to established historical community-educational discourses. The mechanisms at work in the Golden Grove Development differ from the historical rhetoric, in that they rely on subjects being self-regulating in accordance with specified, rational and calculable codes of conduct - codes that would produce economic, educated and 'good' subjects, collectives and populations. The role of the developers thus becomes ethical, with regard to its concern with the conduct of individuals and groups and with the way in which these bodies conduct themselves.

The aim of this paper has been to acknowledge and contest suburban government and, in particular, the production of 'community' as a tangible phenomenon. I have argued, along with others, that 'community' is not a producible commodity, rather it is a complex mesh of relationships - relationships that may or may not emerge from planning processes and practices. I have illustrated my argument using the Golden Grove Development district centre discourses to demonstrate how the developers of the Golden Grove MPC sought to produce ideals of the 'educated/good community'. The developers at the time (1988) believed the district centre and the shared secondary school campus in particular represented a 'true example of community integration with Australian-wide significance for the development of new urban growth areas' (South Australian Urban Land Trust, 1988, p. 8). This claim is supported by recent research done by Costley on MPC in Australia (Costley, 2006, p. 164) and her finding that 'developers of ... MPCs realize the importance of education, not only for children but for families, neighbourhoods and community cohesion and support.'

The co-location of facilities and social mix were two key rationales underpinning the production of the 'educated/good community' in the Gold Grove Development district centre discourses. In practice, both these rationales proved problematic and difficult to implement. The co-location of public and private secondary schools on one campus failed to produce the ideas of community that the developers had envisioned. In recent years, the shared schools campus has been the target of vandalism (Sunday Mail, 2004) and security measures on the campus have been heightened, limiting access to and between the three schools. In addition, the presence of youths in the shopping precinct car park at night, among other reasons, prompted some residents to lobby for a police station to be built in the area. The site of the new police station however was not to be co-located with the district centre facilities. The reasons for this and the current use of the district centre facilities constitute an ongoing research project, the results of which have yet to be determined.

The intent of this paper has not been to argue for specific changes to planning and development processes that constitute MPC. Rather this paper set out to acknowledge and recognise the meanings and values inherent in community discourses. This then opens up possibilities to think about and practice planning differently, in ways that are more ethical and equitable. 


\section{Acknowledgements}

This paper is drawn from the author's $\mathrm{PhD}$ thesis, which was completed in 2005. In addition, the author wishes to acknowledge and thank the two anonymous referees for their insightful and supportive comments on an earlier draft of this paper.

\section{References}

Alperson, P., ed., 2002. Diversity \& community: an interdisciplinary reader. Malden: Blackwell.

Bell, D., 2005. The emergence of contemporary masterplans: property markets and the value of urban design. Journal of urban design, 10 (1), 81-110.

Boseman, C., 2007. The making of suburban heritage: building 'community', cultural significance and planning practices. In: C. Miller and M. Roche, eds. Past matters: heritage \& planning history - case studies from the Pacific Rim. Newcastle: Cambridge Scholars, 81-103.

Bosman, C., 2004. 'Homes for Everyone'. Journal of Australian studies, 80 (Write/Up: New Talents 21C), 131-145.

Bosman, C., 2005. Building 'Community': sites of production, planning practices \& technologies of suburban government in the making of the Golden Grove development, 1984-2003. Unpublished PhD thesis. Adelaide: University of South Australia.

Bosman, C., 2007. Building community places-Machizukuri- neoliberalism, suburbanization and 'Americanization'. International planning studies, 12 (4), 1-17.

Bosman, C., 2009. Building a Golden Grove 'community': a study of suburban production processes in South Australia, 1970s-1980s. Planning perspectives, 24, (1).

Costley, D., 2006. Master planned communities: do they offer a solution to urban sprawl or a vehicle for seclusion of the more affluent consumers in Australia? Housing, theory and society, 23 (3), 157-175.

Delfin Management Services, 1992. Golden Grove Development business plan 1992/93. Delfin Property Group unpublished report.

Dewey J., 1897. My pedagogic creed. Infed http://www.inf ed.org/archives/e-texts/e-dew-pc.html.

Dowling, R. and McGuirk, P., 2007. Understanding master-planned estates in Australian cities: a framework for research. Urban policy \& research, 25 (1), 21-38.

Everingham, C., 1995. The imagined community of access and equality. Proceedings from the Social Policy \& The Challenges Of Social Change: National Social Policy Conference, Sydney: University of New South Wales, 5-7 July, Vol. 2, 25-39.

Foucault, M., 1991. Discipline \& punish: the birth of the prison. London: Penguin Books.

Freie, J., 1998. Counterfeit community: the exploitation of our longings for connectedness. Maryland: Rowman \& Littlefield.
Frug, G., 1999. City making: building communities without building walls. Princeton: Princeton University Press.

Gleeson, B. and Low, N., 2000. Revaluing planning: rolling back neo-liberalism in Australia. Progress in planning, $53,83-164$.

Golden Grove (Indenture Ratification) Act, 1984. Government of South Australia.

Golden Grove Community Planning Team, 1990. Golden Grove Community Plan: an update of the 1987 Community Plan. Unpublished report.

Gwyther, G., 2008. The doctrine of social mix in the mobile society: a theoretical perspective. Housing, theory and society. iFirst.

Hall, P., 1994. Urban and regional planning. London: Routledge.

Hall, K. and Porterfield, G., 2001. Community by design: new urbanism for suburbs \& small communities. New York: McGraw-Hill.

Haworth, A., 1976. Planning and philosophy: the case of Owenism and Owenite communities. Urban studies, 13 (2), 147-153.

Holmes, M., 1995. Social mix in Metropolitan Adelaide: a case study of the Golden Grove area. Unpublished BA hons thesis. Adelaide: University of Adelaide.

Hunter, I., 1994. Rethinking the school: subjectivity, bureaucracy, criticism. St Leonards: Allen \& Unwin.

Huxley, M., 1994. Planning as a framework of power: utilitarian reform, enlightenment logic and the control of urban space. In: S. Ferber, C. Healey and C. McAuliffe, eds. Beasts of suburbia. Melbourne: Melbourne University Press, 148-169.

Katz, P., ed., 1994. The new urbanism: toward an architecture of community. New York: McGraw-Hill.

Keogh, J., 1996. Governmentality in parent-teacher communications. Language \& education, 10, 119-131.

Knudsen, D., Metro-Roland, M., Soper, A. and Greer, C. eds. 2008. Landscape, tourism, and meaning, new directions in tourism analysis. Burlington: Ashgate.

Law, J., 2006. After method: mess in social science research. Abingdon: Routledge.

L.G. Curtis and Associates, 1977. Brief for marketing strategies report Modbury/Golden Grove. Government of South Australia unpublished report.

Martin, J., 1996. Building 'Community'. Urban land, 55 (3), 28-32; 55-56.

Mayfield, J. and Trimper, K., 1989. Golden Grove: a secondary education complex in South Australia. Paris: OECD, report for Programme on Educational Building.

Minnery, J. and Bajracharya, B., 1999. Visions, planning processes and outcomes: master planned communities in South East Queensland. Australian planner, 36 (1), $33-41$.

Murphy, C., 1993. Haystacks to cul-de-sacs. Tea Tree Gully: Golden Grove Development Committee and the City of Tea Tree Gully.

Neal, P., ed., 2003. Urban villages \& the making of communities. London: Spon Press.

Northage \& Associates Pty Ltd, 1983. Golden Grove: development initiatives. A study of objectives and 
arrangements for the Golden Grove Development. Government of South Australia unpublished report.

Owen, R., 1969. Robert Owen on education. H. Silver ed. London: Cambridge University Press.

Pettit, D., 1980. Opening up schools: school \& community in Australia. Ringwood: Penguin Books.

Richards, L., 1991. Nobody's home: dreams \& realities in a new suburb. Melbourne: Oxford University Press.

Rosenblatt, T., Cheshire, L., and Lawrence, G., 2009. Social interaction and sense of community in a master planned community. Housing, theory and society, 26 (2), 122-142.

Ryder, T., 2003. Flying: master planned communities. Property Australia, 17 (6), 12-15.

Smith, S., 1988. Adelaide makes world history in education. 19 April, Government of South Australia press release.

Smith, M., 2001. John Dewey, Infed http://www.infed.org/ thinkers/et-dewey.html.

South Australian Land Commission, 1979. Tea Tree Gully (Golden Grove) Development Area study. Adelaide: Government of South Australia, unpublished report.

South Australian Urban Land Trust \& Delfin Property Group, 1986. Golden Grove Development: ReviewDecember 1986. Promotional report.

South Australian Urban Land Trust \& Delfin Property Group, 1988. Golden Grove community/secondary education complex. Promotional report.

Stretton, H., 1989. Ideas for Australian cities. Sydney: Transit.

Sunday Mail, 2004. This is someone's idea of a good time. 29 August: 17, newspaper.

Talen, E., 1999. Sense of community and neighbourhood form: an assessment of the social doctrine of new urbanism. Urban studies, 36 (8), 1361-1380.

Talen, E., 2000. The problem with community in planning. Journal of planning literature, 15 (2), 171-184.

Talen, E., 2002. The social goals of new urbanism. Housing policy debate, 13 (1), 165-188.

Tea Tree Gully Golden Grove Development Committee, 1980. Development Scheme No 1. Government of South Australia tender document.

Tract (S.A)., 1976a. Comprehensive development plan: Modbury-Golden Grove. South Australian Land Commission unpublished report.

Tract (S.A)., 1976b. Modbury Golden Grove Structure Plan: the structure plan, Vols 1-4. South Australian Land Commission unpublished report.

Village Shopping Centre publicity brochure, c1992.

Whitlam, E., 1971. The political powers and policies needed for effective planning. Architecture in Australia, 60, 709-712.

Wild, R., 1981. Australian community studies \& beyond. Sydney: Allen \& Unwin.

Young, I., 1990. The ideal of community and the politics of difference. In: L. Nicholson, ed. Feminism/postmodernism. New York: Routledge, 300-323. 